\title{
Author Correction: Novel inhibitors targeting Venezuelan equine encephalitis virus capsid protein identified using In Silico Structure- Based-Drug-Design
}

Sharon Shechter ${ }^{1}$, David R. Thomas ${ }^{2}$, Lindsay Lundberg ${ }^{3}$, Chelsea Pinkham ${ }^{3}$, Shih-Chao Lin $\mathbb{1}^{3}$, Kylie M. Wagstaff ${ }^{2}$, Aaron Debono ${ }^{4}$, Kylene Kehn-Hall ${ }^{3}$ \& David A. Jans ${ }^{2}$

Correction to: Scientific Reports https://doi.org/10.1038/s41598-017-17672-9, published online 18 December 2017

This Article contains errors.

The reference to the PDB entry was missing. It is included below as Reference 1, and should be cited in the Methods section under the subheading 'Preparation of the IMP $\alpha$ structure for docking' as follows:

"Virtual screening was carried out on the IMP $\alpha$ :VEEV NLS crystal structure [PDB:3VE6, 2.83 A resolution] ${ }^{1}$."

\section{Reference}

1. Fan, F. Crystal Structure Analysis of Venezuelan Equine Encephalitis Virus Capsid Protein NLS and Importin Alpha. doi: 10.2210/ $\mathrm{pdb} 3 \mathrm{VE} 6 / \mathrm{pdb}$

(i) Open Access This article is licensed under a Creative Commons Attribution 4.0 International License, which permits use, sharing, adaptation, distribution and reproduction in any medium or format, as long as you give appropriate credit to the original author(s) and the source, provide a link to the Creative Commons license, and indicate if changes were made. The images or other third party material in this article are included in the article's Creative Commons license, unless indicated otherwise in a credit line to the material. If material is not included in the article's Creative Commons license and your intended use is not permitted by statutory regulation or exceeds the permitted use, you will need to obtain permission directly from the copyright holder. To view a copy of this license, visit http://creativecommons.org/licenses/by/4.0/.

(C) The Author(s) 2018

${ }^{1}$ Shechter Computational Solutions, Andover, MA, USA. ${ }^{2}$ Nuclear Signaling Laboratory, Department of Biochemistry and Molecular Biology School of Biomedical Sciences, Monash University, Melbourne, Australia. ${ }^{3}$ National Center for Biodefense and Infectious Diseases, School of Systems Biology, George Mason University, Manassas, VA, USA. ${ }^{4}$ Monash Institute of Pharmaceutical Sciences, Parkville, Victoria, Australia. Sharon Shechter and David R. Thomas contributed equally. Correspondence and requests for materials should be addressed to S.S. (email: Shechter. solutions@gmail.com)or D.A.J. (email: david.jans@monash.edu) 